J. Perinat. Med. 15 (1987) 258

\title{
Angiotensin converting enzyme activity in hypertensive pregnancy
}

\author{
Milton I. Lee ${ }^{1}$, Sidney F. Bottoms', Robert J. Sokol' ${ }^{1}$, and Herbert M. Todd ${ }^{2}$ \\ ${ }^{1}$ Wayne State University, Hutzel Hospital, Detroit, Michigan, and ${ }^{2}$ St. Louis \\ University, St. Louis, Missouri, U.S.A.
}

\section{Introduction}

Components of the renin-angiotensin system have been implicated repeatedly in hypertensive disorders of pregnancy $[3,10,11]$. However, the role of angiotensin converting enzyme (ACE) in blood pressure regulation during pregnancy has rarely been investigated. This enzyme catalyzes the conversion of angiotensin I to angiotensin II, a potent vasopressor and deactivates a vasodepressor, bradykinin, thereby raising blood pressure. Vascular endothelium is the primary source of ACE $[2,8,9]$ and it can be measured in plasma or serum. Studying 18 normotensive primigravida, OATs et al. [7] found ACE levels to be significantly lowered during normotensive pregnancy and to be dependent on gestational duration. Whether the activity of this enzyme is altered in hypertensive disorders of pregnancy has not been determined. The purpose of this study was to determine whether serum ACE activity is significantly different in subjects with hypertension during late pregnancy from that in normotensive gravidas.

\section{Methods}

Thirty pregnant women were investigated, of whom 16 were hypertensive and 14 were normotensive. The hypertensive group consisted of 12 nulliparous and 4 multiparous women 28 to 36 weeks' gestation, consecutively hospitalized for evaluation and treatment of their disease.

\section{Curriculum vitae}

Milton I. Lee, $M$. D., was born in 1940. He studied medicine at the University of Michigan, U.S.A., from which he was graduated in 1972. Following Residency Training at the University of Michigan and a Fellowship at Harbor/ UCLA Medical Center, he joined the St. Mary's Health Center at St. Louis

University. Since 1983 he has been an Assistant Professor of the Division of Maternal-Fetal Medicine, Wayne State University, Detroit. His main field of interest are hypertensive disorders of pregnancy.

These subjects were studied less than 24 hours after being admitted and prior to any treatment other than bed rest. None were on medications or restrictive diets prior to admission or investigation. Ten of the twelve nulliparas had moderate pregnancy induced hypertension (PIH) and two had PIH superimposed on chronic hypertension, according to criteria previously published [5]. Their diastolic blood pressures were less than $110 \mathrm{~mm} \mathrm{Hg}$, and proteinuria was less than $3+$ on dipstick determination. Two of the four multiparous women had chronic hypertension before developing superimposed PIH and had been medicated intermittently prior to conception; the two remaining women developed 
the hypertension and proteinuria syndrome de novo. Their diastolic blood pressures were $90 \mathrm{~mm}$ of $\mathrm{Hg}$ or above, on at least two occasions six hours apart and $2+$ proteinuria was present by dipstick determination.

The normotensive (control) group consisted of 4 multiparas and 10 nulliparas women 29 to 40 weeks gestation, who regularly attended the obstetrics clinics and who consented to participate in the study. They denied restrictive diets or ingestion of medication other than prescribed prenatal vitamins and iron. Their diastolic blood pressures were never greater than $75 \mathrm{~mm} \mathrm{Hg}$ and the systolic pressures did not exceed $130 \mathrm{~mm} \mathrm{Hg}$ during the prenatal period. None of these subjects demonstrated proteinuria during their pregnancies.

Examination of the optic fundi, lungs and heart was within normal limits for all subjects at the time of the investigation. Results of serum transaminases, urea nitrogen, bilirubin and coagulation profiles in members of the PIH group were within normal limits on the day of admission to the hospital. Gestational duration was determined by agreement within one week between last menstrual period and by real time ultrasound cephalometry.

A blood pressure cuff was placed on the right arm prior to placement of a 19 gauge heparin lock in the right forearm at the beginning of the study. Subjects were rested in the left lateral decubitus position for 20 minutes in a quiet room. Blood pressures were determined by auscultation using the first (systolic) and fifth (diastolic) sounds of Korotkoff, and repeated immediately; mean values were recorded and diastolic pressures used for analysis. Our standard methods for blood sample collection included removing of $4 \mathrm{ml}$ blood through the lock over 2 minutes and permitting the specimen to stand and clot 3-4 hours prior to centrifuging for 5 minutes at $3000 \mathrm{rpm}$. Thereafter, the serum was removed for storage at -20 degrees $\mathrm{C}$ until assayed for ACE activity.

Serum levels of ACE activity were determined in duplicate samples using spectrophotometric methods described by LIEBERMAN [6]. The collected serum was incubated with the substrate Hip-His-Leu (Calbiochem, Calif) at 37 degrees $\mathrm{C}$ for 60 minutes. The hippuric acid generated was extracted with ethyl acetate in a heating block at 100 degrees $\mathrm{C}$ and redissolved in normal saline. The absorption of this solution was read after 15 minutes at $228 \mathrm{nM}$ on a Beckman Du-8 B spectrophotometer set to zero against distilled water.

All results are reported as means \pm S. D. Data analysis was done using unpaired $t$-tests when appropriate and stepwise regression using the BMDP Statistical Software Package (University of California, 1982). A p $<.05$ was consid'ered significant.

\section{Results}

Significant differences between the two groups were found in mean diastolic blood pressure, ACE activity and chronological age. There was no difference in gestational duration. These findings are shown in table I. Stepwise regression analysis was done with ACE activity as the dependent variable and diastolic pressure, gestational duration and maternal age as independent variables. The results are shown in

Table I. A comparison between ACE activity, diastolic blood pressure, maternal age and gestation duration $( \pm$ S. D.) in hypertensive $(n=16)$ and normotensive $(n=14)$ subjects $28-40$ weeks gestation.

\begin{tabular}{lllll}
\hline & $\begin{array}{l}\text { ACE activity } \\
\text { (units) }\end{array}$ & $\begin{array}{l}\text { Diastolic } \\
(\mathrm{mm} \mathrm{Hg})\end{array}$ & $\begin{array}{l}\text { Maternal age } \\
\text { (years) }\end{array}$ & $\begin{array}{l}\text { Gestation } \\
\text { (weeks) }\end{array}$ \\
\hline Hypertensives & $21 \pm 4$ & $81 \pm 12$ & $22 \pm 5$ & $32 \pm 3$ \\
Controls & $13 \pm 5$ & $51 \pm 11$ & $26 \pm 6$ & $34 \pm 3$ \\
$\mathrm{p}<$ & .001 & .001 & .05 & NS \\
\hline
\end{tabular}


Table II. Summary table for stepwise regression analysis of the relationships between ACE activity and diastolic blood pressure, gestation duration and maternal age in 16 hypertensive and 14 normotensive gravidas $28-40$ weeks gestation.

\begin{tabular}{llllll}
\hline $\begin{array}{l}\text { Step } \\
\text { No. }\end{array}$ & Variable & Multiple & & $\begin{array}{l}\text { Increase } \\
\text { in } \mathrm{R}^{2}\end{array}$ & F to enter \\
\hline 1 & $\mathrm{R}$ & .501 & .251 & .251 & 9.366 \\
2 & Diastolic pressure & .555 & .308 & .057 & 2.252 \\
3 & Gestation duration & .558 & .311 & .003 & 0.104 \\
\hline
\end{tabular}

ACE activity $=$ dependent variable, $\mathrm{n}=30$

table II. Of the three factors tested, only diastolic blood pressure was significantly related to ACE activity $\left(\mathrm{R}^{2}=25 \%, \mathrm{p}<.04\right)$. Once diastolic blood pressure entered the equation, there was no longer any significant relation of maternal age or gestational duration to serum ACE level.

\section{Comments}

The key finding of this study is that serum ACE activity is significantly elevated in subjects with $\mathrm{PIH}$, a finding in this series not accounted for by differences in maternal age or gestational duration. A possible explanation for this observation is that $A C E$ is stored within pinocytotic vesicles of capillary vascular endothelium $[2,9$, $10]$ and the enzyme may be released into the maternal circulation from deranged vascular endothelium observed in PIH. Such angiopathic changes have been described in hypertensive pregnant women [4].

Alternatively, it might be suggested that advancing chronological age correlates negatively with ACE activity [6], and could be a confounder of our findings. Indeed, the hypertensive subjects in this study tended to be younger than controls. However, as shown in the multiple regression, age did not significantly relate to ACE levels when blood pressure was taken into account. A third possibility relates to the fact that the activity of this enzyme can be altered by other diseases, notably sarcoidosis [6]. None of the subjects investigated in this series had positive histories or demonstrated evidence of system disease other than hypertension. Thus, based on this small series, the first explanation appears the most likely.

Although mean diastolic blood pressures may appear relatively low for hypertensive subjects, blood pressures were carefully taken and repeated immediately in the right arm after the subjects had been resting tranquilly in the left lateral position for at least 20 minutes in a quiet room.

A comparable investigation of ACE activity in 16 hypertensive gravidas at 36 weeks' gestation and 17 normotensive women at 40 weeks' gestation was performed by RASMUSSEN et al. [8]. Serum levels of ACE activity in the hypertensive group of RASMUSSEN and colleagues [8] were very similar to those found in the 16 subjects with PIH in the current study, $20 \pm 3$ vs $21 \pm 4$ units, respectively. In addition, in the current study, levels of ACE activity were depressed (13 \pm 5 units) in normotensive gravidas, in agreement with the findings of OATS et al. [7] who reported a depression in this enzyme's activity during normotensive pregnancy, when compared with the nonpregnant state. RASMUSSEN et al. [8] did not observe a similar decrement in normotensive pregnancy, apparently accounting for their failure to detect a relative increase in ACE levels in their hypertensive gravidas. Reasons for this discrepancy with regard to ACE levels in normotensive pregnancy remain speculative and warrant additional study. 
Given that ACE levels are, indeed, typically lowered in normotensive pregnancy, current findings raise an interesting clinical question: Does the relative elevation in serum ACE activity observed in patients with PIH precede the development of clinical evidence of the disorder? If so, might this test be useful as a predictor of the developing disease? Additional studies will be necessary to answer these questions.

\begin{abstract}
Summary
Recent investigations suggest angiotensin converting enzyme (ACE) activity is generally decreased in normotensive pregnancy, but less is known about the level of activity of this enzyme in hypertensive pregnant subjects. The primary source of ACE is vascular endothelium and it can be measured in serum or plasma. In a preliminary investigation, we measured and compared diastolic blood pressure and serum ACE activity in 14 uncomplicated pregnant subjects during the third trimester, and in 16 subjects of similar gestation duration hospitalized with pregnancy-induced hypertension PIH. No patient
\end{abstract}

had a positive history for, or evidence of, pulmonary or other metabolic disease. Compared with levels in normal pregnancy, serum ACE activity was found to be significantly elevated in PIH. In this study, this increase was not due to differences between the groups in maternal chronologic age or gestational duration. Further studies are necessary to determine if the increase in ACE activity precedes or follows development of clinically apparent $\mathrm{PIH}$. If the former is the case, ACE activity might be a useful indicator of risk for PIH.

Keywords: Angiotensin converting enzyme (ACE), blood pressure, hypertension, normotension, pregnancy induced hypertension (PIH).

\section{Zusammenfassung}

\section{Aktivität des Angiotensin-Converting-Enzyms bei Hyper- tonie in der Schwangerschaft}

Neuere Untersuchungen zeigen, daß die Aktivität des Angiotensin-Converting-Enzyms (ACE) bei normotensiven Schwangeren im allgemeinen reduziert ist; über die Aktivität dieses Enzyms bei Hypertonie in der Schwangerschaft ist jedoch wenig bekannt. Die Hauptquelle des $\mathrm{ACE}$ ist das vaskuläre Endothelium; die Messung kann im Serum oder im Plasma erfolgen. In einer früheren Studie wurden der diastolische Druck und die ACEAktivität im Serum bei 14 komplikationslosen Schwangerschaften während des letzten Trimenons gemessen und verglichen mit denen von 16 Schwangeren, die we- gen einer H-Gestose hospitalisiert waren. Bei keinem der Patienten lagen Hinweise für Lungen- oder Stoffwechselerkrankungen vor. Wir fanden signifikant erhöhte ACESpiegel bei H-Gestose. In der vorliegenden Studie konnten wir nachweisen, daß dieser Anstieg nicht auf Unterschiede zwischen den Gruppen bezüglich des mütterlichen Alters oder der Schwangerschaftsdauer zurückzuführen war. Weitere Untersuchungen sind notwendig, um festzustellen, ob der Anstieg der ACE-Aktivität der klinischen Manifestation einer H-Gestose vorausgeht oder folgt. Geht der Anstieg voraus, könnte die Bestimmung der ACE-Aktivität zur Abschätzung des Risikos für eine $\mathrm{H}-$-Gestose von Nutzen sein.

Schlüsselwörter: Angiotensin-Converting-Enzym (ACE), Blutdruck, H-Gestose, Hypertonie, Normotonie, Schwangerschaft.

\section{Résumé}

Activité de l'enzyme de consersion de l'angiotensine et hypertension gravidique

Des investigations récentes suggèrent que l'activité de l'enzyme de consersion de l'angiotensine (A. C. E.) diminue habituellement au cours de la grossesse chez la femme normotendue, mais on en connait moins sur le niveau d'activité de cette enzyme chez les femmes enceintes hypertendues. La première source d'A. C. E. est l'endothélium vasculaire et on peut le mesurer dans le sérum ou le plasma. Dans une étude préliminaire, nous avons mesuré et comparé la pression sanguine diastolique et l'activité sérique A.C.E. chez 14 femmes ayant une grossesse sans complication au cours du troisième trimestre et chez 16 femmes au même terme hospitalisées pour une hypertension purement gravidique (P. I. H.). Aucune patiente ne présentait d'antécédents ni de signe d'affection pulmonaire ou métabolique. On a trouvé que l'activité sérique $A$. C. E. est significativement plus 
élevée dans le groupe P. I. H. que dans le groupe grossesse normale. Dans cette étude, cette élévation n'est pas secondaire à des différences entre les 2 groupes en ce qui concerne l'âge maternel ou le terme gestationnel. Des études ultérieures sont nécessaires pour déterminer si l'élévation de l'activité A. C. E. précède ou suit l'apparition de la P. I. H. cliniquement apparente. Si la deuxième éventualité s'avère exacte, l'activité A.C. E. pourrait être un indicateur utile de P. I. H.

Mots-clés: Enzyme de consersion de l'angiotensine (A. C. E.), grossesse, hypertension, hypertension gravidique pure, pression sanguine.

Acknowledgements: This investigation was supported in part by a research grant sponsored by City Hospital, St. Louis, Missouri. We wish to express special acknowledgement to DeE HarTMAN, LARRY CHIK, $\mathrm{Ph}$. D., and Pauline GeTZIE for their assistance in data management and preparation of the manuscript.

\section{References}

[1] AIKEN JW, JR VANE: The renin-angiotensin system: Inhibition of converting enzyme in isolated tissue. Nature 228 (1970) 30

[2] Caldwell PR, BC Seegal, RC Hsu, M Das, RL SOFFER: Angiotensin-converting enzyme: vascular endothelial localization. Science 191 (1976) 1050

[3] Gant NF, GL Daley, S Chand, PJ Whalley, PC MCDonALD: A study of angiotensin II pressor response throughout primigravid pregnancy. J Clin Invest 52 (1973) 2682

[4] Govan AD: The pathogenesis of eclamptic lesions. Pathol Microbiol 24 (1961) 561

[5] LeE MI, C Hobel, G OAKES: Hypertensive disorders of pregnancy, method of Conn's Current Therapy (edited by HF CoNN), p 835. Saunders, Philadelphia 1982

[6] LIEBERMAN J: Elevation of serum angiotensin-converting enzyme (ACE) level in sarcoidosis. Am J Med 59 (1975) 365

[7] OATS JN, FB PIPKIN, EM Symonds: Angiotensinconverting enzyme and the renin-angiotensin system in normotensive primigravid pregnancy. Clin Exp Hypertens 73 (1982) 91

[8] Rasmussen AB, EB Pedersen, FK Romer, $P$ JOHANNESEN, S KristensEN, JG LAURITSEN, M WOHLERT: The influence of normotensive preg- nancy and pre-eclampsia on angiotensin-converting enzyme. Acta Obstet Gynecol Scand 62 (1983) 341

[9] RYAN JW, US Ryan, DR SchUlTz, C Whitaker, A CHUNG: Subcellular localization of pulmonary angiotensin-converting enzyme (kininase II). Biochem J 146 (1975) 97

[10] Smith U, JW Ryan: Pinocytotic vesicles of the pulmonary endothelial cell. Chest 59 (Suppl) (1971) $12 \mathrm{~s}$

[11] Tolledo OE, LC Chesley, FP Zuspan: Reninangiotensin system in normal and toxaemic pregnancies III. Differential sensitivity to angiotensin II and norepinephrine in toxaemia of pregnancy. Am J Obstet Gynecol 100 (1968) 218

[12] Weir RJ, R Fraser, AF LeVer, JJ Morton, JJ Brown, A Kraszewski, GM McIlwaINe: Plasma renin, renin substrate, angiotensin II, and aldosterone in hypertensive disease of pregnancy. Lancet I (1973) 291

Received September 5, 1985. Revised January 13, 1986. Accepted April 18, 1986.

Milton I. Lee, M. D.

Hutzel Hospital

Department of Obstetrics and Gynecology

4707 St. Antoine

Detroit, Michigan 48 201, U. S. A. 